\title{
Observations on Mr. Sturgeon's letter contained in the Lond. and Edinb. Phil. Mag. for November 1834
}

\section{Mr. Francis Watkins}

To cite this article: Mr. Francis Watkins (1835) Observations on Mr. Sturgeon's letter contained in the Lond. and Edinb. Phil. Mag. for November 1834, Philosophical Magazine Series 3, 6:33, 239-239, DOI: $10.1080 / 14786443508648586$

To link to this article: http://dx.doi.org/10.1080/14786443508648586

册 Published online: 01 Jun 2009.

Submit your article to this journal $₫$

Џll Article views: 2

Q View related articles $\square$

Citing articles: 1 View citing articles ๘ 
OBSERVATIONS ON MR. STURGEUN'S LETTER CONTAINED IN THE LOND. AND EDINB. PHIL. MAG. FOR NOVEMBER 1834. BY MR. FRANCIS WATKINS.

To Richard Phillips, Esq., F.R.S., \&c.

My dear Sir,

On looking over your valuable Journal for the last year, I was somewhat surprised to find in the November Number a letter from Mr. Sturgeon detailing the results of some experiments which he made in magnetv-electricity the 28th of A ugust 1834, with the large steel magnet belonging to the proprietors of the Gallery of Practical Science, Adelaide Street, Strand.

I take the liberty of calling your attention to the fact, that many months previously to the date of Mr. Sturgeon's experiments, (namely, on the evening of the 14th of November 1833,) I had the pleasure conjointly with Mr. Saxton (the projector and maker of the large and splendid magnet exhibited in Adelaide Street,) of illustrating in the presence of yourself, Messrs. Faraday, Lardner, Turner, Daniell, Cooper, Moseley, Pepys, and a host of other scientific gentlemen assembled at the Gallery, the mechanical, physical, and chemical effects of electricity developed by steel magnets.

You will, no doubt, recollect that on the evening in question I superintended a large magnetic machine which was very kindly lent at my solicitation by the Count de Predevalle, and constructed for that nobleman by the ingenious artist M. Pixii of Paris, while on the same evening $\mathrm{Mr}$. Saxton displayed the splendid powers of the instrument contrived and made by himself.

There is nothing in these observations intended to underrate the merits of Mr. Sturgeon; indeed, I feel assured, had that gentleman been aware of what had been already done, he would not have forwarded his letter for insertion in your Magazine. Mr. Sturgeon I well know to be an ardent and zealous labourer in the field of physical science, and I hope you will allow me here to record, that I have received many friendly and valuable hints from that gentleman. Yet in justice to Mr. Saston and myself, I could not let the opportunity pass of bringing to your recollection what had been achieved and experimentally illustrated months before the date of Mr. Sturgeon's experiments.

Should you consider it worth while to insert these remarks in your Miscellany, your readers will be apprised that what Mr. Stur geon brings forward as new in magneto-electricity in August 1834, had been noticed by Mr. Saxton, myself, and others, many montls previously. And it may here be observed, that notices of polar decomposition by magneto-electric agency were published in some French journals about the latter end of the year 1832 .

I remain, my dear Sir, yours faithfully,

5, Charing Cross, Jan. 22, 1835.

Francis Watkins. 